\title{
New IUCN Headquarters
}

$\mathrm{T}$ he splendid new headquarters of the World Conservation Union were inaugurated on 3 November 1992 by President of the Swiss Confederation René Felber at a ceremony which was probably the most moving to conservationists since the time of the International Union for the Protection of Nature more than 40 years ago.

The Swiss authorities - Federal (Bern), Cantonal (Vaud), and Communal (Gland) - combined resources to provide the land and to fund construction of the building just off the Route Suisse, near the shores of Lake Léman, between Geneva and Lausanne. The total cost came to around 20 million Swiss francs, or about US \$17 millions. Of this sum the Confederation contributed SFr. 12.5 millions and the Canton de Vaud SFr. 5 millions. The town of Gland gave the World Conservation Union an $8,800 \mathrm{~m}^{2}$ site, rent-free for 50 years, that is estimated to be worth SFr. 4.2 millions.

Switzerland's global-spirited generosity reflects the recently reaffirmed Government policy to attract many United Nations and international environmental organizations and secretariats to Geneva and the surrounding area, though to disappointed local regret these will not now include the Commission on Sustainable Development even if it does the permanent secretariats of the Climate Change and Biological Diversity treaties, which were both signed by more than 150 countries at the recent Earth Summit in Rio de Janeiro.

Even so, Geneva and vicinity must have by far the

world's richest agglomeration of environmental and conservational organizations, large and small, existing or foreseeable, anywhere in the world, and thus to constitute a natural centre of such interests. Among its most rightly influential leaders are IUCN - The World Conservation Union - which brings together a diverse membership of 59 governments, 92 government agencies (such as the Great Barrier Reef Authority of Australia), and about 550 international and national nongovernmental organizations (NGOs). Altogether it provides a quite unique environmental forum for dialogue between governments and NGOs.

In the last two years, IUCN has grown rapidly. While its Gland Headquarters staff has doubled to nearly 140 , most of the expansion has been outside Switzerland, especially in developing countries: some 300 staff are employed elsewhere in the world. The Union's budget has risen from SFr. 42 millions last year to close to 60 millions this year. But although its staff and budget are still relatively modest in size, the Union plays a key role on the global environmental scene, creating partnerships for conservation and development, and bringing diverse interest-groups together for action and results.

The opening of the sandy-coloured, rectangular headquarters (Fig. 1) coincided with a day-and-a-half symposium on the world environment and the Union's strategic role, summed up by its Director-General, Dr Martin Wyatt Holdgate, as reported briefly on page 370 .

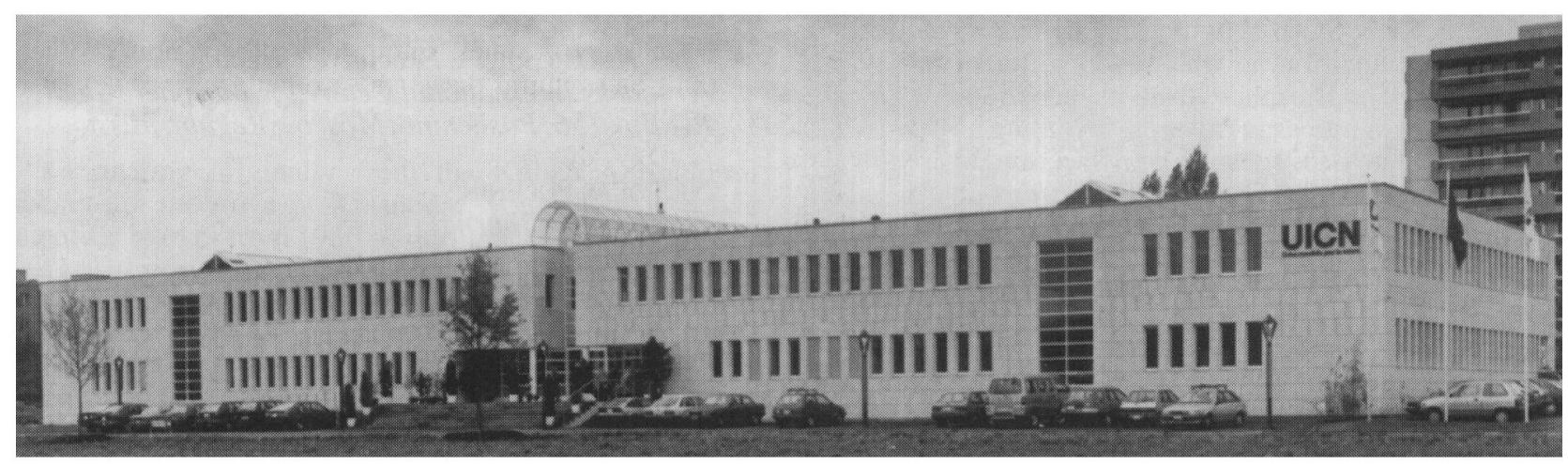

FIG. 1. The new IUCN (UICN in French, the predominant language locally) as seen from near the Route Suisse between Gland and Morges (IUCN's earlier seat) skirting the Lake of Geneva (Lac Léman).

\section{Rio Declaration on Environment and Development*}

Principle 1: Human beings are at the centre of concerns for sustainable development. They are entitled to a healthy and productive life in harmony with Nature.

Principle 2: States have, in accordance with the Charter of the United Nations and the principles of

*Adapted from Connect, the UNESCO-UNEP Environmental Education Newsletter, in which it followed a preamble stating that it was from 'the historic United Nations Conference on Environment and Development, held in Rio de Janeiro, Brazil, 3-14 June 1992.' Over one hundred heads of state and government attended, as did delegates from more than 170 countries, virtually all pledged to preserve the endangered planet and its protective envelope - to the great credit of the organizer, Maurice F. Strong, of Canada, who evidently made them do their homework. - Ed. international law, the sovereign right to exploit their own environmental and developmental policies, [but] the responsibility to ensure that activities within their jurisdiction or control do not cause damage to the environment [or] other States or of areas beyond the limits of national jurisdiction.

Principle 3: The right to development must be fulfilled, so as to meet equitably the proper developmental and environmental needs of present and future generations.

Principle 4: In order to achieve sustainable development, environmental protection shall constitute an integral part of the development process and cannot be considered in isolation from it. 